\title{
Toward Islamic Psychology: \\ Understanding of Mental Illness from Qur'anic Verses
}

\author{
Katimin $^{1}$, Zainal Abidin ${ }^{2}$, Adelina Nasution ${ }^{3}$, Ismail Fahmi Arrauf \\ Nasution $^{4 *}$ \\ ${ }^{1}$ Uiniversitas Islam Negeri Sumatera Utara, ${ }^{2,3,4}$ IAIN Langsa, Indonesia \\ 1profkatimin2@uinsu.ac.id, 2zainalabidin@iainlangsa.ac.id, 3adelinanasution@iainlangsa.ac.id, \\ 4ismailfahmiarraufnasution@iainlangsa.ac.id *(corresponding author)
}

DOI: $10.29240 /$ alquds.v5i1.2482

Submitted: 2021-02-04 | Revised: 2021-03-09| Accepted: 2021-04-12

\begin{abstract}
This article discusses an interpretation of the Qur'an by Abdullah Saeed using the contextual interpretation model. However, this paper will focus on how Abdullah Saeed developed the concept of the hierarchy of values inspired by Fazlur Rahman's thought, which discussed the problem hierarchy of values as general principles. However, Fazlur Rahman did not provide specific devices to develop the hierarchy of values. Abdullah Saeed developed and formulated the concept hierarchy of values into five levels, including obligatory values, fundamental values, protective values, implementational values, and instructional values. The five hierarchies of values become a complete unified frame as an effort to the contextual interpretation of the Qur'an, especially the ethico-legal verses that mostly fill the daily life of most Muslims based on the understanding of maqashid al-sharia and the concept of good deeds. This study uses a descriptive analysis method and hermeneutic analysis techniques to apply the concept hierarchy of values in the Qur'anic interpretation. The results of this paper are in the contextual interpretation of QS. Al-Hujurat verses 1-18 contain the five hierarchical levels of values that have been specifically conceived by Abdullah Saeed.
\end{abstract}

Keywords: Psychopathology, Alquran, Islamic Thought, Scientific Integration, Islamic Psychology.

\section{Introduction}

The difficulty of a scientific field to solve the problem of a subject often occurs because of the limitations of the methodology possessed by a scientific discipline. To overcome this problem, there is an offer to study a problem subject through several scientific disciplines. Because each scientific discipline has a different methodology, therefore, it also has variation to solve the problem on one subject. The variations offered from various scientific perspectives are 
expected to facilitate the resolution of a problem. For this reason, scientific papers have emerged to offer interdisciplinary studies.

At the PTIQ Institute (Institute of Qur'anic Science) Jakarta, a dissertation has been written on the conceptual offer of building psychopathology in Islam or Islamic psychopathology ${ }^{1}$. In essence, this offer is very paradoxical because Islamic psychology itself, as the mother of Islamic psychopathology, has not yet had an established foundation. Therefore, every scientific discipline to be built must have strong scientific references. How can the foundations of Islamic psychopathology are built with the lack of Islamic psychology references?

Among Cipta's worries to the emergence of the purpose of writing a dissertation entitled "The Foundations of Islamic Psychopathology: A Psychophilosophical Approach to the Concept of Mental Disorders and Its Causative Factors in the Qur'an" is the increase in mental disorders faced by humankind ${ }^{2}$. Cipta states that solving the psychological crisis of mankind can be overcome by offering scientific integration or various other interdisciplinary terms. He explains that by this approach, one problem could be reviewed through various approaches to facilitate problem-solving ${ }^{3}$.

The multidisciplinary approach or scientific integration has one main problem that must be addressed, namely the perspective of each scientific discipline on a problem becomes very partial ${ }^{4}$. For example, social psychology is seen by psychology as a psychiatric disorder, religious science sees it as mental damage, and so forth. For this reason, Cipta feels that an integrality of a subject must be found to solve a problem integratively.

Another problem that arises in building the foundations and systems of psychopathology from a religious perspective is the emergence of various terms referring to one locus 5 . This occurs because there is no coordination or

${ }^{1}$ Dissertation is written by Cipta Bakti Gama entitled "The Foundation of Islamic Psychopathology: A Psycho philoshopical Approach to the Concept of Mental Disorders and its Causes in the Qur'an" supervised by a promotor: Prof. Dr. H.M. Darwis Hude, M.Sc and Dr. Abd. Muid. N, M.A.

${ }^{2}$ Cipta Bakti Gama, "Fondasi Psikopatologi Islam: Suatu Pendekatan Psikofilosofis terhadap Konsep Gangguan Jiwa dan Faktor Penyebabnya dalam Al-Qur'an” (PTIQ Jakarta, 2018), 1-2.

${ }^{3}$ Gama, "Fondasi Psikopatologi Islam: Suatu Pendekatan Psikofilosofis terhadap Konsep Gangguan Jiwa dan Faktor Penyebabnya dalam Al-Qur'an.”

${ }^{4}$ M. Amin Abdullah, "New Horizons of Islamic Studies through Socio-Cultural Hermeneutics," Al-Jami'ab: Journal of Islamic Studies 41, no. 1 (2003): 1-24.

${ }^{5}$ Gama, "Fondasi Psikopatologi Islam: Suatu Pendekatan Psikofilosofis terhadap Konsep Gangguan Jiwa dan Faktor Penyebabnya dalam Al-Qur'an.” 
integration between fields of study. An integrative approach must first solve this problem so that there is no paradox in the use of terms.

In his dissertation, Cipta identified seven problems and four problem boundaries. The formulation of the problem is how to formulate the foundations of Islamic psychopathology based on the Qur'anic concept of mental disorders and the factors that cause them. There are six research objectives and six research benefits, each consisting of three theoretical benefits and three practical benefits ${ }^{6}$.

This research uses the method of maudhu'i interpretation formulated by Rasywani. The data collection technique is through literature study. The research approach is qualitative-psycho-philosophical using Paul Ricoeur's hermeneutical: distinction, appropriation, and interpretation ${ }^{7}$.

This article aims to conduct a critical analysis of CiptaBakti Gama's dissertation entitled "The Foundation of Islamic Psychopathology: A Psychophilosophical Approach to the Concept of Mental Disorders and Its Causative Factors in the Qur'an". The main focus of the criticism of this article is the problem of the foundations of Islamic psychopathology and the scientific integration system. In the first part, the writer presents the essential parts of the dissertation. The next section offers a critical review. The focus of his review is on how the dissertation links methodology between scientific disciplines.

\section{Psychopathology and Knowledge Problems}

Psychology is the study of mental illness, mental disorders, and abnormal mental symptoms. Psychopathology is equivalent to the term abnormal psychology, psychiatry, or any discipline that addresses mental disorders $^{8}$. In the second chapter, Cipta describes the conceptual roots in scientific discourse that can be related to the foundations of Islamic psychopathology, with the term psychopathology as a scientific discipline. The presentation is divided into three general aspects, namely discourse on the basic theory of mental disorders, discourse on the basic structure of scientific disciplines, and discourse on Islamic mental science?

According to medical philosophy, mental disorders are:

\footnotetext{
${ }^{6} \mathrm{Ibid}$.

${ }^{7}$ Ismail Fahmi Arrauf Nasution dan Miswari, "Menangkap Pesan Tuhan: Urgensi Kontekstualisasi Alquran melalui Hermeunetika," Jurnal At-Tibyan 3, no. 2 (2018): 229-30.

${ }^{8}$ J.P. Chaplin, Kamus Lengkap Psikologi, XVI (Jakarta: Rajawali Press, 2014), 406.

${ }^{9}$ Gama, "Fondasi Psikopatologi Islam: Suatu Pendekatan Psikofilosofis terhadap Konsep Gangguan Jiwa dan Faktor Penyebabnya dalam Al-Qur'an.”
} 
"Mental disorders are conceptualized as behaviors, psychological syndromes or patterns that appear in individuals that are clinically significant and are associated with a symptom of distress such as pain or impairment/disability in one or more important functions for bumans or with a significant increase in the risk of experiencing suffering in the form of death, pain, disability, or loss of important freedoms ${ }^{\prime \prime \prime}$.

According to Cipta, experts differ on the basic theory of mental disorders. These different views include differences in the basic concept of mental disorders and the dimensions of the causative factors. Cipta said, in medical philosophy, there are five general views on the concept of disease, namely concepts that are medical, subjective, statistical, normative, and biological. First, the medical concept holds that disease is a category defined by doctors. Second, the subjective concept states that the disease is a subjective feeling of the person who experiences it, in the form of pain, discomfort, or disability. Third, the statistical concept states that the disease is actually an abnormality that is assessed statistically. Fourth, the normative concept states that the disease is actually an assessment of something that is not in accordance with the adopted norms. Fifth, the biological concept states that disease is a biological condition in the form of failure to achieve a fit condition to survive and reproduce, or failure to adapt to environmental situations ${ }^{11}$.

This categorization is important because the formulation of the foundation of a scientific discipline requires a foundation (mabani $)$, the basic structure that includes basic assumptions (mabâdï), study subjects (mawdh $\hat{u}$ ), problematics (masâi $i$ ), methods (manhaj), and a community of experts. It also needs a concept about the subject of study. Islamic psychopathology is a multi or interdisciplinary discipline, which includes scientific, philosophical, Sufistic, and scriptural (nash) sciences.

Cipta follows Boorse's view ${ }^{12}$ states that there are five general views on the concept of disease, namely medical concepts (determined by doctors), subjective in the form of subject complaints (both in the form of pain), discomfort, or a sense of inadequacy (disability), statistical (an abnormality that is assessed statistically), normative (an assessment of something that is not in accordance with the accepted norms), and biological (failure to achieve a fit

\footnotetext{
${ }^{10}$ Rusdi Maslim, Buku Saku Diagnosis Gangguan Jiwa: Ringkasan dari PPDGJ-III dan DSM5 (Jakarta: Fakultas Kedokteran Universitas Atmajaya, 2013), 7.

${ }^{11}$ Gama, "Fondasi Psikopatologi Islam: Suatu Pendekatan Psikofilosofis terhadap Konsep Gangguan Jiwa dan Faktor Penyebabnya dalam Al-Qur'an.”

${ }^{12}$ Ibid.
} 
condition to survive and reproduce, or failure to adapt to the environmental situation $)^{13}$.

Kring explained that the concept of mental disorders includes four characteristics: personal suffering (personal distress), disability, violation of norms, and dysfunction, which is a combination of subjective, biological, and normative concepts ${ }^{14}$.

Furthermore, Cipta discussed the relationship between soul and body from various perspectives. There are two broad classes of discourse. First is monism, and the second is dualism. Monists include Berkeley, Fichte, Hegel, Fechner, Mach, W. James, Whitehead, Teilhard de Chardin, B. Rensch, Spinoza, Russell and Feig. Adherents of dualism include Wittgenstein, Leibniz, R. H. Lotze, Wundt, J. H. Jackson, Freud, Hobbes, C. Vogt, T. H. Huxley, K. R. Popper and N. Chomsky.

The purpose of this categorization is to find a mental disorder model from a physical and psychological perspective. There are four important biological models that cause schizophrenia, namely heredity, biochemistry, neurological factors, and neurological anatomy factors. There are also psychological models. According to him, there are four sub-models: psychoanalytic, behavioral, cognitive, and humanist.

Cipta said that the urgency of discussing the foundations of psychopathology really depends on the assumptions held about the basic structure of scientific disciplines. Historically, the topic of the basic structure of scientific disciplines has been discussed by logicians, especially in the Arabicspeaking tradition. Furthermore, Cipta said, entering the early twentieth century, philosophers were also busy discussing this topic as a response to the positivism view, which states that the only knowledge worthy of holding is that which can be objectively verified through observation. In its development, this view has drawn many criticisms, which have led to various alternative positions. The discussion of this problem can be seen from two domains of discourse, namely the discourse of the elements of knowledge in classical logic and the discourse of demarcation of science and nonscience ${ }^{15}$.

${ }^{13}$ Ferry Muhammadsyah Siregar dan Pradiastuti Purwitorosari, Wawasan Kebangsaan dan Kearifan Lokal Bersatu dalam Keanekaragaman untuk Pembangunan Bangsa (Yogyakarta: Sekolah Pascasarjana, Universitas Gadjah Mada, 2013).

${ }^{14}$ Ann M. Kring, Abnormal Psychology (New Jersey: Willey, 2012), 5.

${ }^{15}$ Gama, "Fondasi Psikopatologi Islam: Suatu Pendekatan Psikofilosofis terhadap Konsep Gangguan Jiwa dan Faktor Penyebabnya dalam Al-Qur'an.” 
Referring to the perspective of ushulfigh, for example, two or more disciplines can have the same subject, but they can still be distinguished from the point of view of their study objectives. Psychopathology as a science whose subject is mental disorders seems to be an example. Psychiatric disorders have become the subject of psychiatry, abnormal psychology, and medical philosophy. All three have the same subject of study but with different objectives. Psychiatry aims to look at its medical aspects, abnormal psychology aims to explain psychological conditions, and philosophy aims to see its ontological, epistemological, and moral dimensions ${ }^{16}$.

According to Yazdi, the distinction between knowledge disciplines is not just a subject but can also be the purpose and method used. Also, what needs to be considered is ${ }^{17}$ the formulation of the concept of the subject itself. The reason is, sometimes a discipline names its subject inaccurately so that it seems the same as the subject of other disciplines, even though they actually highlight the different aspects ${ }^{18}$.

Cipta said that the cases of psychopathology in psychiatry, abnormal psychology, and medical philosophy could also be explained through this, namely by looking at the different aspects of mental disorders that are studied by each of the three disciplines. For example, psychiatry looks at mental disorders in terms of medical symptoms, psychology in terms of its relation to the characteristics of the soul in general, and philosophy from its ontological, epistemological, and moral sides ${ }^{19}$.

A problem is a collection of statements that are studied in a scientific discipline. Then it has the terms subject and predicate. The terms subject for statements that become problematic in a scientific discipline has four types, namely: (1) the subject of the discipline itself; (2) the subject of a scientific discipline that is limited by its essential nature; (3) species of the subject of scientific disciplines; and (4) species of subject disciplines limited by their essential nature. In the element of knowledge, the subject is something that is studied, its essential predicate, such as genus, differentiation, implication of genus or differentiation, and essential properties of the genus. The problem is a collection of statements that are studied in a scientific discipline, namely the terms of the subject: (1) The subject of the discipline; (2) the subject of discipline is essential; (3) Species of disciplinary subjects; (4) Species of disciplinary subjects are limited in essential characteristics. The foundations are

\footnotetext{
${ }^{16}$ Ibid.

${ }^{17}$ Ibid.

${ }^{18}$ Muhammad Taqi Mișbāḥ Yazdī, al-Manhaj al-Jadîd fî Ta'lìm al-Falsafah Vol. 1 (Beirut: Dâr at-Ta'ârûf li al-Mathbû'ât, 1990), 75-77.

${ }^{19}$ Gama, "Fondasi Psikopatologi Islam: Suatu Pendekatan Psikofilosofis terhadap Konsep Gangguan Jiwa dan Faktor Penyebabnya dalam Al-Qur'an.”
} 
conceptual: (1) Definition of the subject of discipline; (2) The definition of the disciplinary subject divisions; (3) The definition of the essential properties of the subject of the discipline and its divisions, namely the axioms: (1) Selfexplanatory; (2) Evidenced in other disciplines ${ }^{20}$.

In exploring the concept of human being and psychopathology in the Qur'an, the second group keywords regarding the meaning of human being are nafs, qalb, and ruh in the Qur'an. This group is taken from verses such as, alAn'âm/6:92, Hûd/11:31, Al-Ahzâb/33:10. The interpretations referred to discuss are ar-Râghib al-Isfabânî, ath-Tabarsî, al-Âlùsî.

The third group is shadr, fu' $a d$, and lubb. Cipta explained that the Qur'an uses these terms, in the form of singular and plural nouns, each shadr is used 11 times, shudûr (plural of shadr) is used 33 times, fu' ${ }^{\prime} d$ is used 5 times, af ${ }^{\prime} i d a b$ (plural of $f u^{\prime} a \hat{d}$ ) is used 11 times, and albâb (plural of lubb) is used 16 times. The word lubb in the singular is never used in the Qur'an. Meanwhile, the verses that contain key terms include: an-Na 1/16: 106, az-Zumar /39: 22, ash-Syar /94:1; al-An'âm /6:125; Thâhâ /20:25, al-A'râf /7:2); 3. al-ajj /22:46); 4., Hûd /11:12, al-ijr /15:97, al-An'âm /6:125); 5, Ghâfir /40:19, al-'Âdiyât /100:10; al-A'râf /7:43); 8, an-Nâs.114, Ghâfir /40: 56, al-Qashash /2, an-Najm /53:10, Hebâhîm /14:37, al-Humazah /104:7, al-An'âm /6:110, Hebrews /14:43, al-Baqarah /2:179, al-Baqarah /2:269; ar-Ra'd /13:19, az-Zumar /39:9, al-Mâ‘idah /5:100, Ghâfir $/ 40: 54^{21}$. These meanings are described by Cipta in the following table:

\begin{tabular}{|l|l|c|l|l|l|}
\hline No & \multicolumn{1}{|c|}{ Meaning } & Nafs & Qalb & Ruh & \multicolumn{1}{|c|}{ Information } \\
\hline 1 & Spirit (life) & $\sqrt{ }$ & & & $\begin{array}{l}\text { Nafs = qalb = Rub } \\
\text { life }\end{array}$ \\
\hline 2 & $\begin{array}{l}\text { Essence / self } \\
\text { (Substance) }\end{array}$ & $\sqrt{ }$ & & & \\
\hline 3 & lust, & $\sqrt{ }$ & & & \\
\hline 4 & life & $\sqrt{ }$ & & & \\
\hline 5 & soul & $\sqrt{ }$ & & & \\
\hline 6 & $\begin{array}{l}\text { Dhamir / } \\
\text { Qalbun }\end{array}$ & $\sqrt{ }$ & & & $\begin{array}{l}\text { Lathifah } \\
\text { Rabbaniyyah (Al- } \\
\text { Ghazali) }\end{array}$ \\
\hline 7 & kind & $\sqrt{ }$ & & & \\
\hline 8 & sense & $\sqrt{ }$ & & & \\
\hline 9 & mother & $\sqrt{ }$ & & & \\
\hline
\end{tabular}

\footnotetext{
${ }^{20}$ Karl R Popper, The Logic of Scientific Discovery (London: Routledge, 2015), 11-13.

${ }^{21}$ Gama, "Fondasi Psikopatologi Islam: Suatu Pendekatan Psikofilosofis terhadap Konsep Gangguan Jiwa dan Faktor Penyebabnya dalam Al-Qur'an.”
} 


\begin{tabular}{|c|c|c|c|c|c|}
\hline 10 & Relationship & $\sqrt{ }$ & & & \\
\hline 11 & Adam as. & $\sqrt{ }$ & & & \\
\hline 12 & $\begin{array}{l}\text { human individual } \\
\text { in totality }\end{array}$ & $\sqrt{ }$ & & & \\
\hline 13 & wrath & $\sqrt{ }$ & & & \\
\hline 14 & creature & $\sqrt{ }$ & & & \\
\hline 15 & mind & $\sqrt{ }$ & & & \\
\hline 16 & blood & $\sqrt{ }$ & & & \\
\hline 17 & turn away & & & & \\
\hline 18 & $\begin{array}{l}\text { immaterial heart } \\
\text { in humans }\end{array}$ & $\sqrt{ }$ & $\sqrt{ }$ & & $\begin{array}{l}\text { the consequences } \\
\text { of numbers } 6 \text { and } \\
18\end{array}$ \\
\hline 19 & heart & & $\sqrt{ }$ & & $\begin{array}{l}\text { meaning of } \\
\text { language; the } \\
\text { physicalist } \\
\text { interpretation }\end{array}$ \\
\hline 20 & brain & & $\sqrt{ }$ & & $\begin{array}{l}\text { inspired by modern } \\
\text { science }\end{array}$ \\
\hline 21 & lust & $\sqrt{ }$ & $\sqrt{ }$ & $\sqrt{ }$ & equal to number 1 \\
\hline 22 & $\begin{array}{l}\text { group of high } \\
\text { ranking angels }\end{array}$ & & $\sqrt{ }$ & $\sqrt{ }$ & \\
\hline 23 & jibril & & & $\sqrt{ }$ & \\
\hline 24 & isa & & & $\sqrt{ }$ & \\
\hline 25 & alquran & & & $\sqrt{ }$ & \\
\hline 26 & help & & & $\sqrt{ }$ & \\
\hline 27 & revelation & & & $\sqrt{ }$ & \\
\hline 28 & life & $\sqrt{ }$ & $\sqrt{ }$ & $\sqrt{ }$ & equal to number 1 \\
\hline 29 & $\begin{array}{l}\text { something } \\
\text { hidden }\end{array}$ & & & $\sqrt{ }$ & \\
\hline 30 & $\begin{array}{l}\text { command of } \\
\text { Allah }\end{array}$ & $\sqrt{ }$ & $\sqrt{ }$ & $\sqrt{ }$ & $\begin{array}{l}\text { Based on the analysis of } \\
\text { number } 1 \\
\text { Nafs }=\text { qalb }=\text { ruh }=\text { nyawa }=\text { dha } \\
\text { mir }=\text { kalbu imateri }=\text { amr } \\
\text { Allah=lathifah rabbaniyah }\end{array}$ \\
\hline
\end{tabular}

The references in this section are the considerations of the views of Ibn Mas'ûd, Ibn 'Âsyûr, al-Marâghî, Ibn' Abbâs, 'Alîar-Ridhâ and Thabâthabâ'î. Meanwhile, Cipta also illustrates the significance of shadr, fu'ad, and lubb in human being ${ }^{22}$. 
Cipta explains a general theory about the foundations of Islamic psychopathology, which is based on the interpretation of verses related to mental disorders. Since the scholars have proposed a specific form of this formulation that still needs to be refined, Cipta divides the explanation into four divisions. First, the general context of the Qur'anic narrative related to mental disorders. Second, basic assumptions about humans, mental disorders, and some affected factors. Third, assumptions about the basic structure of Islamic psychopathology refer to a scientific discipline. Fourth, Qur'anic psychopathology is a variant of Islamic psychopathology which is based on the science of interpretation ${ }^{23}$.

Cipta divides the discussion into: 'The General Context of the Explanation of the Qur'an on Mental Disorders which discusses' The Qur'an's Relationship with Scientific and Philosophical Disciplines', 'Main Objectives of the Qur'anic Treatise, and 'The Purpose of the Qur'anic Treatise as a General Context for the Concept of Mental Disorders'. In point 'B' entitled 'The Essence of the Qur'anic Psychopathology', Cipta reviews 'Assumptions about the Various Dimensions and Structure of the Human Self', 'The Nature of Mental Disorders' and 'Factors that cause mental disorders'. In point ' $\mathrm{C}$ ', entitled 'Basic Structure of Islamic Psychopathology', discusses 'Variety of Elements' and 'Four Mirrors Approach' and finally discusses 'Quranic Psychopathology'24.

A rotten heart is the source of mental damage or disorders. Today, mental disorders have a wider scope for scientific study. The scientific subject is called psychopathology. Even in Islamic studies, Islamic psychopathology has begun to be built. CiptaBakti Gama in his dissertation entitled 'Foundations of Islamic Psychopathology: A Psychophilosophical Approach to Mental Disorders and Its Causative Factors in the Qur'an' explores the root terms of mental disorders in the Qur'an and finds terms that are the roots of psychopathology, namely: mardh, zaygh, thughyan, tasyin, taswil, khatm, thab ', qulf, akinnah, rayn, qaswah, zhulmah, and dhiq. These terms are divided into six parts, namely sickness (maradb), being deceived and slipping (asyin and taswit), deviating from and exceeding boundaries (zaygh and thughyan), closed and locked (khatm, akinnah, qufl and thab), rusted and petrified (rayn, qaswab), narrow and dark (dhiq and şulmab).

\section{Maradh}

The term maradh and its derivatives are found twenty-four times in the Qur'an. Its general meaning is out of balance, specifically for the soul. The term applies to both physical ailments and bad morals such as ignorance, cowardice,

${ }^{23}$ Ibid.

${ }^{24}$ Ibid. 
stingy and hypocrisy. This condition is the opposite of being safe and healthy. Cipta describes thirteen of the twenty-four terms maradh and its derivatives are the meaning of psychological illness, namely lying, not knowing the damage of deeds that are considered good, misresponsiveness to worries, blaming religion, not understanding the nature of tawakal, belittling the Qur'an, slandering, thinking badly of Allah, rejects some of the Shari'a, is not good at controlling lust, hurts others, is invited to jibad to fear death, is jealous of the Shari'a, likes what Allah hates and does not understand parables in the Qur'an.

The thirteen psychological illnesses can be divided into four categories, namely attitudes towards society, attitudes towards Allah and His Messenger, attitudes towards oneself, and attitudes towards religious teachings. In QS. AlMaidah: 52, the psychological disorder in question is a person who does wrong because he chooses Jews and Christians to be leaders. QS. Al-Ahzab verse 12 is a hypocrite by saying Allah and His Messenger taught deceit. QS. Al-Anfal verse 49 shows that psychic disorders are people who say that religion is a trick. QS. $\mathrm{Al}-\mathrm{Baqarah}$ verse 10 is a person who does damage but claims he is doing well.

Ibn 'Arabi said that this mental illness was a doubt about the teachings of the Prophet Muhammad, thus issuing statements that raised doubts. This disease is ignorance that turns away from God, is vain, obsessive, and loving the world. Tabattaba'i said that the disease was out of a state of nature so that it deviated from the path of returning to Allah. Mulla Sadra explains that the disease is a disease of the heart as a deadly poison by believing that bad is good, hypocritical, and envious. This disease is a fundamental cause of social psychopathology, one of which is intolerance ${ }^{25}$.

\section{Deceived: Tasyin and Taswil}

Being deceived in the terms tasyin and taswil is the appearance of evil as good. QS. Al-Hujarat verse 7 says that deceived people are those who do not believe in the hereafter so that their deeds are beautiful. Because they do not believe in the hereafter, they lose their purpose, become confused and even consider the world itself as an end. Confused people usually seek psychological comfort by glorifying rational arguments, which are esoterically symbolized by the stars (arguments) in the nearest sky (ratio) in QS. Shaffat verse 6.

Being deceived in taswil arises from within as Joseph's brothers did to deceive their father (QS.Yusuf verse 18) and Samiri who deceived the people of Prophet Musa (QS. Thaha verse 92). Tazyin then appears in the context of leaders who create the impression of badness as good (Al-An'am: 39). Other

\footnotetext{
${ }^{25}$ Ismail Fahmi Arrauf Nasution, Miswari, dan Ilham Dwitama Haeba, “Traditionalism of Tolerance in Dayah System: A Reflective Note on the Biography of Abon Aziz Samalanga of Aceh," Religia 23, no. 1 (2020), https://doi.org/0.28918.
} 
forms of deception are apostasy, disobeying the Prophet, worshiping the sun, judging without knowledge, being hindered from the straight path and the state for those who are hostile to Allah. In a social context, these tricks are actualized in the form of betrayal and misunderstanding of religion which has consequences for socio-political attitudes.

Another cheating is loving the world (QS. Ali Imran: 14) and considers bad actions as good as a result of being deceived by Satan (QS. Fathir verse 8).

\section{Deviation and Transgression}

The term raygh means to deviate, and thaghah means transgressing. In the Qur'an, following Al-Isfahani's opinion, Cipta said that the two words and their derivations were used in the same meaning. These words are used thirty-nine times in the Qur'an. The ratio is Pharaoh, bashar, water, humans, some bad behavior, previous people, ablul kitab (the people of the scriptures), the voice of azan, hypocrites, polytheists who do not want to meet God and Taghut. On his mi'raj journey, as mentioned in QS. An-Najm verse 17, Prophet Muhammad is called no zagha (turning away) and nor tagha (transcending).

Meanwhile, the raygh terminology on qalb is written in QS. Ash-Shaff verse 5 , in a request that the heart does not go astray (laa-turigh) after being given instructions. Zaygh is a deviation from guidance, not fearing Allah. It is a form of following the wishes. In an exoteric meaning, as stated by Al-Maraghi, Cipta explained that this term means disbelief and denial. Meanwhile, in an esoteric sense, Al-Kasyani interprets it as an attraction to the world.

4. Closed and Locked

Closed and locked have the terms khatm, akinnah, qufl and thab. In terms of kha-ta-ma, the meaning is perfection or the arrival of something at the end, tha-ba-'ain means to determine something in its condition, qaf-fa-lam is to cover something clearly, kaf-nun-nun is to protect something by closing it. Cipta found only twenty words of the terms above that are relevant to psychopathology. All of these are attributes for qalb. The object of discussion of khatm is a quality that cannot be warned, negligent with worldly achievements, divinizes wishes (lust), and acts of lying in the name of Allah. Akinah is attributed to three objects, namely the inability to understand the explanation of the Prophet Muhammad, turning away from warnings, and turningaway from the Book. Thab is mentioned in talks about breaking the covenant, love of the world, exaggeration, doubting the Prophet Muhammad, blocking from the path of Allah.

People who give negative responses to the explanation of the Prophet Muhammad are included in that negative terminology (QS. Ghafir verse 35). They argue with the Prophet without solid arguments. They doubt the teachings 
of the Prophet. Such people are locked in their hearts so that they cannot receive guidance, lose their power of reason, and become like crazy people and their hearts die. In an esoteric sense, these people are those who have gone astray with a tendency to worldly elements.

5. Rusty and Petrified

Rayn is rusty, and qaswah is petrified. Rayn is the rust of what was originally bright. Qaswah is something that becomes hard, which is attributed to the heart. Rayn was ordained to people who denied the Qur'an, doubted the resurrection day, sinned beyond limits. It happens because the heart is covered with rust. In the Hadith riwayah Ahmad, when a person commits one sin, a stain appears in his heart. When he leaves his sins and acts of giving, his heart will be clean again. Ciptaas quoted in Fakhruddin Al-Razi states that part of the sin was to keep oneself busy with worldly affairs. Esoterically, it means not being able to receive light.

A stony heart becomes difficult to accept the influence of the teachings of kindness. Its characteristics are being old-fashioned, long-minded, and not sad of making sin, displeasing to obey God. The remedy is to be friend with the needy, go to an assembly of wise people, fast, pray at night and submit to Allah. Laughing too hard makes hearts petrify. Losing khusyu gradually makes hearts petrify. Aisyah said that those who like to eat, to sleep, and to rest make their heart petrified.

6. Narrow and Dark

Dhiq is narrow, and dark is zbulmah. This condition applies to the heretical person who is not warned, hypocritical, disbelieving, lives in vain, is negligent, hinders goodness, and is more interested in worldly things.

Such a disease is the assumption that inclination to worldly things is not a problem. That it turns out to be a bad attitude and deeds. That is bad. Moreover, it turns out that this attitude is a great danger. They forget the pleasure of meeting Allah.

This dissertation concludes that the foundations of Islamic psychopathology are formulated in an integrative form that includes the biopsycho-socio-spiritual dimension and demands multidisciplinary study. This is based on the interpretation of the verses that use the words insân, basyar, nâs, nafs, qalb, rûh, shadr, fu' âd, lubb, sam ', bashar,' aql, syahawât, hawâ, fithrah, and their various derivatives; verses on basic emotions; also verses that use the words maradh, zaygh, thughyân, tasyin, taswill, khatm, thab ', qufl, akinnah, rayn, qaswah, $z h u l m a h$, and $d h \hat{\imath} q$, along with their various derivations. These verses indicate that humans have a biophysical dimension, a psychic dimension (sense of perception, affection, conation, and rational cognition), a social dimension, and a spiritual dimension. These verses also indicate that the various dimensions of 
the human can deviate from the proper characteristics (healthy character), which is the core concept of mental disorders. Then these verses also indicate that mental disorders are greatly influenced by the health of the spiritual dimension, in addition to other dimensions.

The Quranic concept of human, mental disorders and the factors that cause it can be formulated into a number of definitions, postulates, and assumptions and basic elements of the discipline of Islamic psychopathology.

This dissertation also proposes a four-mirror approach theory as a framework for the study of Islamic psychopathology, which is integrative and multidisciplinary. This theory assumes that knowledge is a reality in the knowing subject, and the essence of the knowing process is the perfect movement of the subject towards and prepares himself to receive the emanation of knowledge from its source, namely Allah through the spiritual realm. This theory also assumes that there are two ways to gain knowledge: (1) Self-purification; and (2) Reflecting on various media that reveal various sciences in the individual. For Islamic psychopathology, this theory emphasizes reflection on philosophical, empirical, scriptural, or religious doctrines based on texts and mystics, especially philosophical tasawn ${ }^{6}$.

\section{Critical Review; Scientific Integration Problem}

"In the context of Islamic psychopathology whose subjects and problems include biophysical, psychic, sociocultural and spiritual dimensions, the epistemological and methodological tools he needs cannot be limited by empirical or rational characters, but need to open up to various other channels." ${ }^{27}$

The paradox arises when Cipta discovers that scientific integration does not actually have an established epistemological foundation so that the initial intention to build a scientific integration system in solving a problem is not achieved $^{28}$. Therefore, although Cipta hopes that by building a scientific integration system, a problem can be handled together, it turns out that a problem cannot be handled together. In a scientific system where each scientific

${ }^{26}$ Gama, "Fondasi Psikopatologi Islam: Suatu Pendekatan Psikofilosofis terhadap Konsep Gangguan Jiwa dan Faktor Penyebabnya dalam Al-Qur'an.”

${ }^{27}$ Ibid.

${ }^{28}$ Cipta Bakti Gama, "Reduksionisme Eksplanatif untuk Antropologi Transendental Jawadi Amuli," Kanz Philosophia: A Journal for Islamic Philosopby and Mysticism 5, no. 2 (2015): 150, https://doi.org/10.20871/KPJIPM.V5I2.133. 
field has its own approach, one problem must be seen differently. There is no integration between disciplines.

Even some intellectuals from Cipta'salmamater, namely STFI Sadra, said that scientific integration was only an act of coercion because there was no established epistemology of scientific integration. There are those who consider the Al-Farabi Scientific Integration book compiled by Dr. Humaidi from the results of research at UIN SyarifHidayatullah Jakarta as the foundation for the existence of scientific integration, at least in the perspective of $\mathrm{Al}-\mathrm{Farabi}^{29}$, but his fellow ICAS-Paramadina alumni said Al-Farabi did not build a paradigm or epistemology of scientific integration ${ }^{30}$. Al-Farabi only investigated the characteristics of each scientific field. This scientific integration is claimed only for the "ego" of each scientific discipline. Moreover, the scientific integration formulated at UIN (State Islamic University) is only an attempt to show that UINization makes sense. The IAIN (State Institute of Islamic Studies) should only focus on the field of Islamic studies. If the scientist is Islamic, that is what is accepted as the Islamization of science. So, the Islamization of science or integration does not lie in the concept but in its output ${ }^{31}$.

The task of scientific integration is indeed very complicated, especially since the task that Cipta took on in his dissertation was not only integration but also building a foundation of Islamic psychopathology. Cipta must carry out several tasks, namely finding similarities between popular scientific sciences, Islamic philosophy, Sufism, and the science of interpretation of psychopathology. So that Cipta needs to integrate four scientific disciplines at once to build a new scientific foundation called Islamic psychopathology.

Science, Islamic philosophy, Sufism, and interpretation have a very broad interpretation for each discipline. For example, science in the case of psychology, especially psychopathology, has various streams. Therefore, Cipta should only choose one representative figure to be able to focus as a handle on psychopathological science, because even though the school of science is chosen, it will also be very broad and full of polemics. Cipta should determine a stream in Islamic philosophy as well.

The five perspectives of disease put forward by Cipta by quoting Boorse, namely medical, subjective, static, normative and biological adequate ${ }^{32}$,

${ }^{29}$ Osman Bakar, Hierarki Ilmu (Bandung: Mizan, 1993), 97-98.

${ }^{30}$ Interview with Iklash Budiman, A philosophy lecturer at STFI Sadra, 12 Desember 2018

${ }^{31}$ Mulyadhi Kartanegara, Integrasi Ilmu: Sebuah rekonstruksi Holistik (Bandung: Arasy, 2005), 48.

${ }^{32}$ Christopher Boorse, "Concepts of Health and Disease," dalam Philosophy of Medicine (Amsterdam: Elsevier, 2011), 21-22. 
each of these types should have an adequate portion of the discussion in order to get a good explanation, but unfortunately that portion is not sufficient. In fact, Cipta focuses too much on subjective and normative diseases. In particular, the discussion of normative diseases is too long but incomplete, so that instead of explaining it, it creates confusion ${ }^{33}$.

Actually, the concept of mental disorders according to medical, psychologists, and philosophers has no practical relationship. Even about the basic theory of mental disorders, both regarding its basic concepts and the various dimensions and causes, Cipta only focuses on scientific and philosophical discourses. Cipta refers a lot to the utterances of Indonesian writers. These authors refer only to psychologists and Western psychological thinkers. Cipta's reference in this section only looks at psychological discourses so that the literary perspective is very segmentary. Cipta should be able to include a psychological study of a philosophical perspective discussed by great philosophers such as Ibn Sina, Mulla Sadra, Descartes and Kant ${ }^{34}$, because in fact the roots of psychological discourse come from the thoughts of great philosophers. All the sources of the basic theory of each scientific discipline cannot be separated from the influence of the great philosophers. But Cipta didn't involve them. Even epistemologists are only beginning to be involved in discussing the basic structure of scientific disciplines.

In explaining the elements of knowledge in classical logic, including Cipta discusses how to determine the subject of a scientific discipline. He said that each discipline may have the same subject but with different goals ${ }^{35}$.

Cipta's explanations in parsing this discussion will not be understood by people who do not understand large philosophical works. For example, when Cipta discusses the problematics of scientific disciplines by using biology as an example, statements such as "every living organism has a soul", "every vegetable living organism cannot move freely", will not be understood and there is no guarantee to be agreed upon if it has not understood the system of soul levels discussed by great philosophers such as Aristotle, Ibn Sina and Mulla Sadra ${ }^{36}$.

In fact, what is very difficult to find from Cipta's dissertation unless observing it carefully is that he has a tendency and is even oriented towards certain groups in every point of his discussion. In Chapter two, for example,

\footnotetext{
${ }^{33}$ Gama, "Fondasi Psikopatologi Islam: Suatu Pendekatan Psikofilosofis terhadap Konsep Gangguan Jiwa dan Faktor Penyebabnya dalam Al-Qur'an.”

${ }^{34}$ Miswari, Filsafat Terakhir (Lhokseumawe: Unimal Press, 2016), 121, 116, 219, 237.

${ }^{35}$ bandingkan Abdul Hadi Fadli, Logika Praktis (Jakarta: Sadra Press, 2016), 76.

${ }^{36}$ Miswari, Filsafat Terakbir.
} 
Cipta dominates references from local authors in the discussion of the basic theory of mental disorders, Cipta dominates Arabic references in elements of knowledge in classical logic even though there are also many other references, especially Western. Then he nominated Western references in the discussion of the demarcation of knowledge $e^{37}$.

In terms of the problem of demarcating knowledge, Cipta has put forward various scientific criteria, starting from the thoughts of Ayer, Popper, Kuhn, Lakatos and Bunge. There is a problem at this point of discussion, namely that Cipta criticizes all the epistemologists, including Bunge. Second, he made no attempt to explain the outcome of the discourse. At this point, Cipta did not try to find a way out of the problem of scientific integration ${ }^{38}$.

In a discussion of psychology in classical literature, Cipta discussed the concepts of the soul and mental disorders in Islamic philosophy and Sufism. The philosophical orientation of mental disorders is a problem of thinking errors, while the orientation of Sufism studies about mental disorders is the distance between humans and God. Sufism and Islamic philosophy have different approaches and orientations regarding the concept of psychopathology. In fact, the two differ in understanding the soul. So how can this study be related to the study of modern scientific psychopathology?

If the two things that are close together, namely Islamic philosophy and Sufism, are very different. How to integrate it with science, whose foundation is almost entirely incompatible with Islamic philosophy and Sufism? It is because Cipta divides references from different sources at each point. Whereas, in the realm of classical psychology, there are other sources besides those in Islamic philosophy and Sufism ${ }^{39}$.

In essence, Sufism and the psychology of science have no relationship at all. First, the meaning or locus of the soul referred to by the two genres is different. The soul in the understanding of psychology is speculative. The soul in understanding Sufism (amali) is doctrinal. Sufism problem is a textual problem. Problems in psychology are empirical phenomena. Both have different problems, approaches and orientations, even more suitable. Cipta does not divide psychology into classical and contemporary realms, but psychology into textualistic (scriptual) and contextual problems (scientific approach).

\footnotetext{
${ }^{37}$ Gama, "Fondasi Psikopatologi Islam: Suatu Pendekatan Psikofilosofis terhadap Konsep Gangguan Jiwa dan Faktor Penyebabnya dalam Al-Qur'an.”

${ }^{38}$ Ibid.

${ }^{39}$ Taqi Miṣbāḥ Yazdī, al-Manhaj al-Jadîd fì Ta'lìm al-Falsafah Vol. 1.
} 


\section{Scientific Basic Problem}

Psychopathology is a part of psychology. Likewise, Islamic psychopathology is part of Islamic psychology. But Cipta himself admits that Islamic psychology is a discipline that is still looking for primary forms ${ }^{40}$. Meanwhile, the essential orientation of Cipta's dissertation is to form the foundation of Islamic psychopathology. This is problematic due to the foundation of Islamic psychopathology cannot be formed since the main foundation is not yet established. The assumption was that even if Cipta succeeded in realizing his ambition, it could not be called Islamic psychopathology because Islamic psychopathology had to rely on Islamic psychology. Meanwhile, in reality, as Cipta admits, Islamic psychology itself is not yet solid.

"In essence, various classical disciplines that have been described previously and it is also continue to develop until now. However, in this section the author will focus more on these two new studies, because on the one hand the development of classical studies is currently more in the form of a restructuring of presentation with content that is not far from classical studies; on the other hand, this research itself tries to be part of this new discourse." ${ }^{41}$

Cipta chose mental disorders and found the terms that were mostly unfamiliar in Sufism and philosophy studies. However, the whole dissertation aims to build an integrative scientific concept involving the science of interpretation, philosophy, and Sufism. In fact, the terms that have relevance to familiar terms in Sufism and philosophy are only used as a derivation of those unfamiliar terms.

Psychic ailments that are presented in the Qur'an are actually very broad lessons so that the interpretation should not be oriented to specific matters. For example in QS. Al-Maidab verses 51-52 concerning the prohibition of making Jews and Christians as leaders by Ubadah ibn Shamit is considered a verse which states that people whose hearts have disease are claimed to be Abdullah ibn Ubay. This specific meaning that judges someone is not worthy of being presented in a study even though Cipta is able to show strong historical references, for example by quoting Tasir At-Tabari, because Cipta's work is oriented as integration for philosophy and Sufism ${ }^{42}$. In philosophy, such as in Sufism, the specification of universal cases, the verse has clearly mentioned that

\footnotetext{
${ }^{40}$ Gama, "Fondasi Psikopatologi Islam: Suatu Pendekatan Psikofilosofis terhadap Konsep Gangguan Jiwa dan Faktor Penyebabnya dalam Al-Qur'an.”

${ }^{41}$ Ibid.

${ }^{42}$ Ibid.
} 
persons are very unwise. Moreover, the verse clearly states that those whose hearts have disease are plural (people), not a person, even though the orientation is universal, it cannot be claimed or attributed to things that have references to concrete reality. Problems in religion that lead to disputes and conflicts are due to legal claims or abstract judgments in texts based on concrete references. In fact, most of them are negative claims.

Cipta's focus is to integrate exoteric interpretations represented by exoteric thinking interpreters with esoteric interpretations by exoteric interpreters ${ }^{43}$. Academically, especially epistemologically and ontologically, it is essential to review from an esoteric and exoteric point of view. Moreover, especially ontologically, the two tendencies have no common ground. They are absolutely different. Each of them is two distinct, non-contradicting identities. Thus, the ontological identity of the exoteric circles, which is generally represented by jurists and mutakallimin, is different from the esoteric circles which are generally represented by 'urafa and some of the lawyers ${ }^{44}$. So that finding a common ground between the two is a futile job ${ }^{45}$.

Philosophically, the integration of theologian and 'urafa might cause a problem. It is inconsistent with logical and scientific principles. If the two ontological principles are different, there is no negotiation at all. In fact, the difference between kalam and 'irfan as well as some philosophies is very basic, namely in the differentiation of conceptual understanding of existence which has implications for differences in understanding the reality of existence ${ }^{46}$. For mutakallimin, form is equivocal, one word but has many meanings. For examples, the word "bisa" might have the meaning "can". It also has the meaning "snake venom". While the univowel is one word, its meaning or locus is also one. For example, in the word "besi" (iron), the reference only applies to iron.

The form for mutakallimin, which means equivocal, is applied to God and creatures. So because God and creatures are two different loci, according to the principles of identity and non-contradiction, then the consequence is, if a creature is a form, then God is not a form. However, 'urafa and some mutakallimin interpret form as univocal. That form can be referred to as God and can be referred to as creatures. As an existence, God and creature is the

\footnotetext{
${ }^{43}$ Ismail Fahmi Arrauf Nasution dan Miswari, "Rekonstruksi Identitas Konflik Kesultanan Peureulak," Paramita 27, no. 2 (2017): 168-81.

${ }^{44}$ Interview with Zulkarnaini, a lecturer at IAIN Langsa, 14 September 2018.

${ }^{45}$ Miswari, Filsafat Langit dan Bumi (Lhokseumawe: Unimal Press, 2018), 137.

${ }^{46}$ Miswari, Filsafat Terakhir.
} 
same ${ }^{47}$. As a side note, this applies to the concept of form. Meanwhile in reality, form is one, but it is graded ${ }^{48}$.

This principle is the absolute differentiator, and no agreement can be made between mutakallimin and 'urafa. Thus, the integration of exotericism and esotericism in Cipta's work has a problem at the heart of metaphysics, on the main subject of intellectuality, and in its ontology. This mistake was made by Ibrahim Kurani in 'Ithaf al-Dhaki in his attempt to find common ground between the teachings of Ibn' Arabi and Abu Hasan Al-Asy'ari ${ }^{49}$.

Cipta in his research wants to integrate eso-exotericism with rational interpretation at the same time. Here, new problems arise. The reference to the rational interpretation perspective is dominated by Fakhruddin Razi. Generally, Fakhruddin Razi was known as a philosopher. But if his theological studies are explored, then he is more worthy of being called a theologian.

Actually, Razi was a theologian just like Al-Ghazali. It is very difficult to distinguish between philosophers and theologians. Both use rational argumentation. The best way to spot the differences between the two is to look at their foundation and orientation. The foundation used by a philosopher is the accuracy of propositions and other rational rules. The orientation is also consistency of reasoning.

While the characteristics of the theologian, there is something that is believed, claimed to be the truth, namely texts, the Qur'an or hadith. They do use rational reasonings, but they will not be consistent, especially when they find inconsistencies between reasoning and the texts they understand. The consistency of the theologian is not in the accuracy and consistency of reasoning but in understanding the texts because from the beginning they have had a conclusion, a belief that is an understood text. Proposition and reasoning are only used to explain and seek rationalization of texts.

A philosopher will only be consistent with propositions and reasoning if they find a text that is not in accordance with the reasoning, while after examining the proposition and reasoning carefully and thoroughly, then what they do is to check the understanding of the text. This method is done by philosophers. Ibn Rusyd uses this method in understanding the texts ${ }^{50}$.

\footnotetext{
${ }^{47}$ Gama, "Fondasi Psikopatologi Islam: Suatu Pendekatan Psikofilosofis terhadap Konsep Gangguan Jiwa dan Faktor Penyebabnya dalam Al-Qur'an.”

${ }^{48}$ Interview with Muhammad Nur Jabir, Directur Rumi Institute, 8 September 2018.

${ }^{49}$ Miswari, Filsafat Terakbir, Miswari, Filsafat Langit dan Bumi.

${ }^{50}$ Afrizal M, Ibn Rusyd Ulama dan Cendikiawan (Jakarta: Erlangga, 2006), 39.
} 
In the results of his dissertation, CiptaBaktu Gama found an overview that the keywords of the Qur'an related to psychopathology are not the same as conventional psychopathological theories. The reason is, the orientation of the Qur'an is divine. That is, in general, the Qur'an aims at a comprehensive human life and focuses on a more important life, namely the hereafter. However, Cipta shows that there are three groups of Muslim intellectuals who have different views on the relevance of the Qur'an with scientific studies or philosophical studies. The first is those who support such as Al-Ghazali, Fakhruddin Razi, Ibn Sina and Mulla Sadra. The second is the opposing party, such as Ash-Syatibi and Mahmud Syaltut. Third are those who argue that certain details of the Qur'an are relevant to science and philosophy, such as Sayyid Qutb, Thabataba'i, and JafarSubhani ${ }^{51}$.

Cipta himself was more interested in supporting the scientific interpretation model (tafsir ilmi) by exploring key concepts from the Qur'an. However, personally, Cipta is more interested in prioritizing scientific considerations or discoveries and then inviting the interpretation of key concepts of the Qur'an to be relevant to the Qur'an. For example, science has shown that the earth is round. Cipta is more inclined to that conception of science even though the Qur'an itself has shown that the earth is spread out, firash, like a mat, like a mattress. There is no round mattress. So it can be said that the Qur'an itself is more impressive that the earth is flat. Cipta himself is more interested and has more faith in the conception of science ${ }^{52}$.

\section{Scientific Integration Constraints (Obstacles)}

Cipta has said that there are three models of integration of science with the Qur'an. First is to apply the concept of science as the meaning of the Qur'an; second is to explore scientific concepts from the Qur'an; and third is to use scientific concepts to help understand the scientific cues of the Qur'an. And as explained above, Cipta himself is more inclined towards the second, namely exploring the scientific concept of the Qur'an. However, besides the discussion of his dissertation, Cipta did not agree with the second model, which is actually the basis for the concept of scientific integration built on his study of the foundations of Islamic psychopathology. Based on his discussions, he was even more inclined towards the first model, namely applying the concept of science as the meaning of the Qur'an as in the case of the earth's shape ${ }^{53}$.

\footnotetext{
${ }^{51}$ Gama, "Fondasi Psikopatologi Islam: Suatu Pendekatan Psikofilosofis terhadap Konsep Gangguan Jiwa dan Faktor Penyebabnya dalam Al-Qur'an.”

${ }^{52} \mathrm{Ibid}$.

${ }^{53}$ Interview with Cipta Bakti Gama, a lecturer at STFI Sadra, 6 Januari 2019.
} 
In fact, Cipta has shown that the focus of the Qur'an is more on matters of divinity, religion, so he decided to continue his research to compile a foundation of Islamic psychopathology by compiling the concept of integration of science and the Qur'an that needs to be questioned ${ }^{54}$. Even Cipta himself admits that he agrees with classical logicians and epistemologists who state that each science has its own unique subject, foundation and problem ${ }^{55}$. Therefore, the Qur'an cannot be used to explore the subject of science. Cipta admitted that each scientific discipline has its own strict system. But for this reason, Cipta is interested in participating in the discourse of science integration or in various other terms such as multidisciplinary studies, Islamization of Naquib Al-Attas' science, Islam as the science of Kuntowijoyo's ideas and the integrated interconnection of Amin Abdullah's ideas ${ }^{56}$.

Cipta admitted that he participated in scientific discourse with a multidisciplinary approach. However, he just collects the focus of psychopathology which is the subject of his research by collecting interdisciplinary philosophy, interpretation, science, and Sufism by making it an inspiration for psychological science. Nevertheless, this is an honest acknowledgment of the various formulations of scientific integration and interconnection in existing scientific discourses where there is no solid scientific argument in their preparation. It is true that these scientific disciplines have different subjects, approaches and orientations. Each scientific discipline is a non-contradictory identity that cannot be mixed in subject, approach and orientation. The most suitable example has been given earlier with the difference between kalam and 'irfan.

In the case of Cipta's dissertation, the science of interpretation cannot be approached and oriented like the approach and orientation of philosophy and Sufism and vice versa. But in this case, it indicated that Cipta was inconsistent or hesitant when he accepted that the Qur'an is not a scientific book. But he believes that in the Qur'an there are some parts of it have scientific signs ${ }^{57}$.

When accepting that the Qur'an is not a scientific book, it is axiomatically accepting that the scientific approach is not the Qur'anic approach

\footnotetext{
${ }^{54}$ Gama, "Fondasi Psikopatologi Islam: Suatu Pendekatan Psikofilosofis terhadap Konsep Gangguan Jiwa dan Faktor Penyebabnya dalam Al-Qur'an.”

${ }^{55}$ Fadli, Logika Praktis.

${ }^{56}$ Kuntowijoyo, Islam Sebagai Ilmu: Epistemologi, Metodologi dan Etika, II (Jakarta: Teraju, 2004); Syed Muhammad Naquib Al-Attas, Islam dan Filsafat Sains (Bandung: Mizan, 1995); Abdullah, "New Horizons of Islamic Studies through Socio-Cultural Hermeneutics."

${ }^{57}$ Quraish Shihab, MukjizatAl-Quran (Bandung: Mizan, 1996), 86.
} 
and the scientific orientation is not the orientation of the Qur'an, so that the recognition that some Qur'an has scientific cues is inconsistent. As such, the parts of the Qur'an that are recognized or considered to be scientific signals have made a scientific approach and orientation to the Qur'an. If not, then there will be no scientific impression and meaning on the Qur'an until the recognition of scientific signs in the Qur'an will emerge.

The orientation of the Qur'an is the benefit of the servant. The servant is all creatures or all things other than God. Unfortunately, Cipta limits the servant to humans only. Consequently, all the messages of the Qur'an seem to please humans only. Most likely, the lack of ecological awareness is the result of a paradigm like this. Quoting various sources, from the description of Cipta, it can be stated that the orientation of the Qur'an is the improvement of faith and righteous deeds, believing in apostolate, believing that Islam is a religion of nature, social benefit, physical and spiritual fulfillment, explaining Islamic law and awareness of the struggle for human rights ${ }^{58}$.

In the orientation related to the research subject, namely psychology, the orientation of the Qur'an is humanization, humanizing humans, keeping humans in their natural state. All the concepts in the Qur'an that have been previously described are symptoms that have shifted from a state of nature. In the spirit of the Qur'an, the improvement of all these symptoms is centered on improving the faith ${ }^{59}$.

The essence of psychopathology determines cognition (creativity), affection (feeling), conation (intention), and psychomotor (work). In humans, there is a dimension of pure, holy, solid to understand the essence of something. Cipta succeeded in showing the human dimension that can be divided into biophysical, psychological, sociocultural, and spiritual dimensions. This finding makes Cipta inclined towards Hanna DjumhanaBastaman's view on the integration of Islamic Psychology with Islam: Towards Islamic Psychology rather than Baharuddinin the Paradigm of Islamic Psychology: A Study of Psychological Elements from the Qur'an ${ }^{60}$.

In essence, what Cipta describes about Bustamam's work is not very relevant to the main focus of the dissertation's discussion. There are only a few contacts. It just so happened that the contact was more with Bustamam than Baharuddin. In fact, this intersection is not important to Cipta's work. The only

\footnotetext{
${ }^{58}$ Gama, "Fondasi Psikopatologi Islam: Suatu Pendekatan Psikofilosofis terhadap Konsep Gangguan Jiwa dan Faktor Penyebabnya dalam Al-Qur'an."

${ }^{59}$ Abdul Aziz Ahyadi, Psikologi Agama: Kepribadian Muslim Pancasila (Jakarta: Sinar Baru, 1988), 124.

${ }^{60}$ Hanna Djumhana Bastaman, Integrasi Psikologi Islam dengan Islam: Menjuju Psikologi Islami (Yogyakarta: Pustaka Pelajar, 2011); Baharuddin, Paradigma Psikologi Islami: Studi Tentang Elemen Psikologi dari Al-Qur'an (Yogyakarta: Pustaka Pelajar, 2007).
} 
rational reason for Cipta to link his research to Bustamam's work is so that the discussion is not completely partial with Indonesia.

This research focuses on building a psychopathological foundation based on interpretation, 'irfan and Islamic philosophy. All literatures must refer to the works of outside thinkers. Tafseer refers to interpretations by Middle Eastern scholars, philosophy refers to Persian Islamic philosophy, and 'irfan focuses on Ibn Arabi and several Sufis, particularly the philosophical Sufism of Persia. Although in the first chapter Cipta says that he still refers to Indonesian interpretations such as Tafseer Al-Misbah and Tafseer Al-Azhar, these references are hardly found in the discussion. Even in this discussion on the terminology of Islamic psychopathology sources, the two local interpretations are not referred to at all.

In order that his research is not truly partial or acceptable to the Indonesian people, Cipta tries to find a ladder through the work of Indonesian experts and finds Bustamam as his oracle. Those are the general characteristics of Sadra's ICAS-STFI alumni. Their scientific studies and discourses are too textual so that they appear partial to the Indonesian intellectual discourse.

Cipta should also focus on studying the ontology and epistemology of each scientific discipline. From each of these ontologies and epistemologies, efforts are made to find aspects that can connect between scientific disciplines so that they can find a new offer, namely scientific integration. If each scientific discipline works to study the same subject, even though it produces different perspectives, its integration can be found. Multidisciplinary study itself cannot solve the problem of the subject. Each scientific discipline can conflict in providing answers to the problems of a subject. If not, multidisciplinary studies will be less effective.

\section{Conclusion}

Scientific integration becomes impossible because the basis of each scientific discipline is different. For example, it is impossible to integrate Sufism with philosophy. The foundation of philosophy is reasoning, and the foundation of Sufism is intuition ${ }^{61}$. Both intuition and reasoning are different so that the scientific products produced by each of them cannot be integrated. If you want to integrate Sufism and philosophy, what is the foundation? Intuition and intuition are two non-contradictory identities. There is no intuition-reasoning or reasoning-intuition.

\footnotetext{
${ }^{61}$ Ismail Fahmi Arrauf Nasution, "Mencerna Akar Filsafat dalam Islam,” Ulumuna 17, no. 1 (2013): 1018.
} 
Cipta hopes that in integrating science, interpretation, philosophy, and Sufism are those which cannot be realized. Apart from reasons of differences in foundations and approaches, another reason is the impossibility of one's expertise in many scientific disciplines. If a person becomes an expert in interpretation, it is impossible for him to be an expert in science and philosophy at the same time. Thus, what a scholar can only do is cultivate a scientific subject with an approach to the scientific field that is his area of expertise. Multidisciplinary can only be done jointly by several experts on the same subject.

For example, the subject of psychopathology that Cipta has begun can be approached in a multidisciplinary manner by four experts, namely philosophers, psychology experts, Sufism experts, and interpretive experts. Cipta's work became impossible because he made great efforts himself. The foundation of Islamic psychopathology to be realized involves at least several scientific experts. That is why in an orderly administration, it is required to have several doctors to build a study program.

Finally, what Cipta can do is to offer a perspective of the Qur'an that discusses verses on psychopathology as an inspiration for the foundations of Islamic psychopathology. Cipta should not only discuss methodological boundaries in scientific exploration because each methodology for each scientific discipline is indeed different and valid for its field ${ }^{62}$. Cipta should have explored the ontology and epistemology of each science discussed to produce scientific integration.

\section{Bibliography}

Abdullah, M. Amin. "New Horizons of Islamic Studies through Socio-Cultural Hermeneutics." Al-Jami'ab: Journal of Islamic Studies 41, no. 1 (2003): 1-24.

Abdullah, M. Amin, Islamic Studies di Perguruan Tinggi, Pendekatan IntegratifInterkonektif. Yogyakarta: PustakaPelajar 2006

Afrizal M. Ibn Rusyd Ulama dan Cendikiawan. Jakarta: Erlangga, 2006.

Ahyadi, Abdul Aziz. Psikologi Agama: Kepribadian Muslim Pancasila. Jakarta: SinarBaru, 1988.

Al-Attas, Syed Muhammad Naquib. Islam dan Filsafat Sains. Bandung: Mizan, 1995.

Baharuddin. Paradigma Psikologi Islami: Studi Tentang Elemen Psikologi dari AlQur'an. Yogyakarta: PustakaPelajar, 2007.

\footnotetext{
${ }^{62}$ Nani Widiawati, Pluralisme Metodologi: Diskursus Sains, Filsafat, Dan Tasawuf (Tasikmalaya: Edu Publisher, 2020), 26.
} 
Bakar, Osman. HierarkiIlmu. Bandung: Mizan, 1993.

Bastaman, Hanna Djumhana. Integrasi Psikologi Islam dengan Islam: Menjuju Psikologi Islami. Yogyakarta: Pustaka Pelajar, 2011.

Boorse, Christopher. "Concepts of Health and Disease." Dalam Philosophy of Medicine. Amsterdam: Elsevier, 2011.

Budiman, Iklash. A philosophy lecturer at STFI Sadra, 12 Desember 2018.

Chaplin, J.P. Kamus Lengkap Psikologi. XVI. Jakarta: Rajawali Press, 2014.

Fadli, Abdul Hadi. Logika Praktis. Jakarta: Sadra Press, 2016.

Gama, CiptaBakti. a lecturer at STFI Sadra, 6 Januari 2019.

- "Fondasi Psikopatologi Islam: Suatu Pendekatan Psikofilosofis terhadap Konsep Gangguan Jiwa dan Faktor Penyebabnya dalam AlQur'an.” PTIQ Jakarta, 2018.

—. "Reduksionisme Eksplanatif untuk Antropologi Transendental Jawadi Amuli." Kanz Philosophia: A Journal for Islamic Philosophy and Mysticism 5, no. 2 (2015): 147-64. https://doi.org/10.20871/KPJIPM.V5I2.133.

Jabir, Muhammad Nur. Directur Rumi Institute, 8 September 2018.

Kartanegara, Mulyadhi. Integrasi Ilmu: Sebuah rekonstruksi Holistik. Bandung: Arasy, 2005.

Kring, Ann M. Abnormal Psychology. New Jersey: Willey, 2012.

Kuntowijoyo. Islam Sebagaillmu: Epistemologi, Metodologi dan Etika. II. Jakarta: Teraju, 2004.

Maslim, Rusdi. BukuSaku Diagnosis Gangguan Jiwa: Ringkasandari PPDGJ-III dan DSM-5. Jakarta: Fakultas Kedokteran Universitas Atmajaya, 2013.

Miswari. Filsafat Langit dan Bumi. Lhokseumawe: Unimal Press, 2018.

. Filsafat Terakbir. Lhokseumawe: Unimal Press, 2016.

Nasution, Ismail Fahmi Arrauf. "Mencerna Akar Filsafat dalam Islam." Ulumuna 17, no. 1 (2013): 1018.

Nasution, Ismail Fahmi Arrauf, dan Miswari. "Menangkap Pesan Tuhan: Urgensi Kontekstualisasi Alquran melalui Hermeunetika." Jurnal AtTibyan 3, no. 2 (2018): 223-37.

. "Rekonstruksi Identitas Konflik Kesultanan Peureulak." Paramita 27, no. 2 (2017): 168-81. 
Nasution, Ismail Fahmi Arrauf, Miswari, dan Ilham Dwitama Haeba. "Traditionalism of Tolerance in Dayah System: A Reflective Note on the Biography of Abon Aziz Samalanga of Aceh.” Religia 23, no. 1 (2020). https://doi.org/0.28918.

Popper, Karl R. The Logic of Scientific Discovery. London: Routledge, 2015.

Shihab, Quraish. Mukjizat Al-Quran. Bandung: Mizan, 1996.

Siregar, Ferry Muhammadsyah, dan PradiastutiPurwitorosari. Wawasan Kebangsaan dan Kearifan Lokal Bersatu dalam Keanekaragaman untuke Pembangunan Bangsa. Yogyakarta: Sekolah Pascasarjana, Universitas Gadjah Mada, 2013.

Taqi Mișbāḥ Yazdī, Muhammad. al-Manhaj al-jadîd fì Ta'lìm al-Falsafah Vol. 1. Beirut: Dâr at-Ta'ârûf li al-Mathbû'ât, 1990.

Widiawati, Nani. Pluralisme Metodologi: Diskursus Sains, Filsafat, Dan Tasawnf. Tasikmalaya: Edu Publisher, 2020. 